\title{
Inmunología en la Reproducción Segunda Parte
}

\author{
JOSE PACHECO \\ Departanento de Ginecología y Obstetricia - Facultad de Medicina de San Fémando
}

\begin{abstract}
RFSUMEN
Se revisa la interacción entre los procesos reproductivos e inmunológicos. En la primera parte hicinins énfasis en el conocimiento de los aspectos generales del sistema innune, especialmente de los factores humorales y celulares de la respuesta iomune, y revisamos la reactividad inmunológica durante el embarazo y el papel de la placenta en la interrelación. Fn esta segunda parte, completamos el último aspecto, repasando la interacción de los sistemas inmunolígicos materno y fetal. Se continúa revisando los conocimientos sobre los anticuerpos anliespermatozoides y antiovario, la infertilidad masculina inmunológica, el aborto recurrente y las pérdidas fetales; y se explora los aspectos inmunológicos de la hipertensión inducida del embarazo, la iscinmunización $\mathrm{Rh}$, la hidropesía fetal, las enfermedades del tejido conectivo vascular y' embarazo, la púrpura trombocitopénica autoinmune, el trasplante de órganos y las drogas inmunosupresoras y las infecciones durante el embarazo, la inmunidad y el parto pretérmino y se hace un alcance sobre la aplicación de la inmunología en la anticoncepción.
\end{abstract}

Palabras clave: Respuesta Inmune, Embarazo, Placentu, Anticoncepción, Infertilidad Masculina.

\section{IMMLNOI.OCYY OF REPRODUC'IION. SECOND PART SUNIMARY}

Main aspects of reproductive and inmunological interactions are presented in this review. In the first part, we outlined the current knowledge of the immune system, the humoral and cellular factors, pregnancy modifications of the immune response, and the role of the fetus and the placenta. In this second part, we complete the lattest aspect, reviewing the interaction of the maternal and fetal inmunulogical systems. We continue revising the knowledge on antisperm and antioyary antibodies, male immunologic infertility, repeated abortion and fetal losses, and explore immunologic aspects of pregnancy induced hypertension, diabetes and pregnancy, Rh factor immunization, felal hydrops, vascular connective tissue diseases and pregnancy, autoimmune thrombocytopenic purpora, organ transplantatien and immunosupressive drugs, and infections during pregnancy, immunity and preterm delivery, as well as a brief on immunology applied contraception.

Key Words: Immune Response, Pregnancy, Placenta, Contraception, Male Infertility.

\section{IVTERACCIÓN DE LOS SISTEMAS INNLNOLÓGICOS MATERYO Y FETAL}

Una de las ventijas inmunológicas del feto es la separación entre las circulaciones materna y letal a nivel de la placenta. Sin embargo. csila barrera no es tolalmente injpermeable, ya que conocemos cómo los licmaries felales ingresan a la circulación malcrna desde la oclava scmana de enibarazo; y, es probable, que lambién lo hilgan leucocilos y plaquetas. Así, se ha encontrado que las mujeres con inmunización Rh tienen mayor cantidad de anticuerpos a leucocions que las mujeres sin anticuerpos a los hemalies.

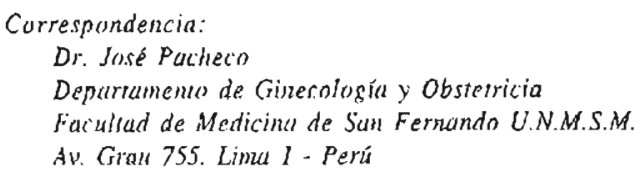

El felo sc protegería de ser rechazado por la existencia de "anticuerpos bloqueadores". Los cmbriones -antigénicamente extraños- no serían dañados por los linfocitos, -capaces de inhibir su crecimicnto celular in virro-, por la existencia lic cierna "protección" del sucro materno. El estímulo para la formación de los "anticucrpos bloqueadores" se iniciaría progresivamente desde la fagocitosis de los espermatozuides en el cana? reproductor y continuaría con la diminuta cantidad de antígenos que contiene el huevo Iccundado, los que siguen liherándose durante un largo tiempo mientras el ambrión se desarrolla. Así mismo, el ingreso de trofoblasto a la circulación matcrna desde el 10o. á l 40. día de implantación y su postcrior lagocilosis estimularía la scnsibilización o tolerancia a lravés de anticuerpos malcrnos "bloqueadores" que circulan por la sangre y se combinan con receptores antigénicos placentarios o lectales (1.2). 
La mujer es inmunizada por los ancígenos fetales, lo cual se evidencia por la demosiración de anticuerpos HLA en las mujeres multíparas, no existentes en las primíparas, y cuyo porcentaje va en incremento de acuerdo al número de hijos. Escos anticuerpos se mantienen después del parto por 17 semanas a más de 4 años. Sin embargo, ellos no son citoróxicos al feto y no afectan la reproducción futura materna.

Despućs de la implantación, la gestante muestra evidencia de reconociniento immune del conceplo intrauterino alogénico. En una proporción de embarazos, particularmente de mujeres mulíparas. existen anticucrpos citotoxicos matemos quc exhiben especificidad por los antígenos HLA paternos heredados del feto. Cuando éstos no son derectables, puede haber otros anticuerpos que no se fijan a complemento o no son cilocóxicos o son anticuerpos que no están presenes como moléculas libres y no es posiblc su identificación por pruebas convencionales. Los anticuerpos anci-HLA no son peligrosos al feco, principalmente debido a su absorción por la placenta y, puede ser, su unión no amenazante de los que llegan a la circulación fecal. En la mayoría de cmbarazos, no ocurre la generacion de linfocitos $T$ citoroxicos delctércos. No se ha establecido en qué medida esto se deba a un control inmunoregulador malerno. El trofoblasto felal es capaz de actuar como una basrcra protectora por virtud de propiedades especiales, incluyendo la falta de moléculas HLA clase I y clase II convencionales, que lo hacen no susceptible al ataque inmune. El trálico celular materno a travez de la placenta ocurre sólo en un nivel muy pcqueño, si ocurre. en el embarazo normal; pero, sí puede ser mayor en los casos raros de cnicrmedad injerto felal-versushúcsped, aunque csto se complica por la inmunodeficiencia letal asociada. Los anticuerpos IgG matcrnos se transmiten a travez del trofublasto placentario por mecanismos dependientes de receptor para proveer protección inmediata al neonaso contra patógenos ambientales. El pasajc de eritrocitos, lcucocitos y plaquetas ferales a la circulación materna puede ocasionar la producción de isoanlicuerpos $\mathrm{IgG}$ que, por los mismos mecanismos, pueden ganar acecso al felo, con consecuencias palológicas. Los auloanticuerpos en mujcres con varias enfermedades pueden pasar de mancra similar al feto, pero cllos normalmente producen sólo efectos leves y transitorios. El desarrollo del sistema inmune lelal empieza en una etapa tcmprana del embarazo, hacicndose competente para responder a las infecciones intrauterinas desde ya las 12 scmanas y icniendo polencial tuncional completo al nacimientn. La IgG ohrenida de la madre la mantiene hasta los 9 meses de vida, hasta que el sistema inmune propio del recién nacido ha sido provocado y aclivado adecuadamente después de su primera exposición a antígenos específicos ( ).

En conclusión, la interacción de las células inmunocompetentes maternas y fetales icndrían lugar:

* en la unión coriodecidual de la placenta;

* en los ganglios linfáticos regionales maternos, a donde llegan a parar las células retales;

* en los órganos hematopoyécicos fetales, como resultado de la transferencia transplacenlaria de células maternas en dirección opuesta.
Y los principales mecanismos que evitarían el rechazo del feto serían:

* la inmadurez antigénica de las células del embrión;

* la antigenicidad disminuida del trofoblasto en la unión materno-fetal, por regulación de los genes de hitocompatibilidad mayor:

* la separación de las circulaciones y sistemas de drenaje linfático de la madre y del felo;

* la producción de anticuerpos bloqucadores málernos a los antígcnos de transpiante fecales;

* alteración de las inmunoglobulinas malernas;

* alteración de la inmunidad mediada por células -linfocitos T y B-, ianto en su número como en su funcionalidad;

* aumento de las hormonas suprarrenales;

* presencia de las hormonas placentarias;

* síntesis de factores de crecimiento polipeptídicos uterinos y placentarios con propiedades inmunosupresivas.

\section{ANTICUERPOS ANTIESPERMATOZOIDES}

Después de las primeras experiencias de Landsteiner, Metchnikoff y Metalnikoft indicadas anteriormente, fue en 1901 que De Leslie observó que ratones albinos machos se volvían escériles por 16 a 20 días al inyectárseles suero anciespermático de cuyes. Mayer y Vogt, en 1922, encontraron que ciertos casos de esterilidad curaban después de un período de abstinencia; Vogt añadía que, en el animal, el primer coito es gcneralmente seguido de embarazo, pero la [ertilidad disminuía posteriormente. Ellos pensaron que éste era el resultado de la formación de una espermatoxina $\left({ }^{\star}\right)$.

El interés clínico por los faclores inmunológicos de la infertilidad humana empezaron cuando, en 1954, Wilson comunjcó que el suero sanguíneo de dos hombres contenía aglutininas para espermatozoides y que estos espermalozoides aglutinaban espontáneamente en gran proporción. Una esposa gestó fácilmente por inseminación heteróloga.

No es difícil comprender cómo pueden producirse anticuerpos contra el espermatozoide, con una incidencia de 1 a $30 \%$ en parejas infértiles $\left({ }^{5}\right)$, ya que el semen humano conticne alrededor de 16 antígenos identificables distribuidos en la cabcza, acrosoma y cola del espermatozoide y en el líquido seminal $\left({ }^{6.7}\right)$. Asi, por ejemplo, el antígeno espermático SAA-I está muy comprometido en el proceso de fertilizacion, siendo posiblemente un receptor de esteroide atípico o un canal iónico localizado dentro de la membrana plasmática del espermatozoide (). La mar.cra como los anticuerpos anticspermatozoides prevendrían la fertilización sería disminuyendo la reacción acrosómica y/o la unión en la zona pelúcida, asi como por efectos postfertilización (s).

Se ha inlormado sobre la presencia de anticuerpos antiespermato\%oides en el suero del hombre y de la mujer, en las secreciones genitales de la mujer y en el csperma de humbres infértiles. También se encuentra anticuerpos después de procesos inllamatorios del testículo o enfermedades oclusivas del conducto deferente o del epidídimo o como consecuencia de la vaseclomía. El estudio de anticuerpos $\operatorname{IgC}$ o IgA secretoria en el moco cervical 
y otros fluídos del aparato reproductor es difícil de realizar y es raro encontrar anticuerpos antiespermáticos en el plasma de mujeres abortadoras habituales, además que su tratamiento no tiene buenos resultados $(4.8,9.10 .11 .12 .13)$.

Debido a lo anterior, s66lo se está estudiando anticuerpos antiespermáticos IgG en el plasma de la mujer cuando la prueba postcoital es anormal. Mientras que el moco hostil es generalmente debido a endocervicitis o a una respuesta inadecuada a los estrógenos, en el problema inmunológico el espermatozoide llega a penetrar el moco, se le adhiere el anticuerpo IgG trasudado del suero de la mujer o el producido localmente y es aglutinado o inmovilizado. Como intento de resolver los casos de fertilidad de origen inmunológico, se emplea los preservativos, los corticoides, la inseminación artificial y otras técnicas de reproducción asistida (15.8.13). Sin embargo, la experiencia actual nos ha llevado a la conclusión que la existencia de anticuerpos en el suero o secreciones genitales de la mujer sólo dificultan algo su fertilidad, pero no la impiden ( 4 )

También se sugiere que los linfocitos de la mucosa tubaria puedan estar involucrados en el proceso de tolerancia immune, lo que permiliría el transporte de espermatozoides y de blastocistos por el oviducto en condiciones normales, sin la aclivación de mecanismos inmunes locales. El tejido linfoide de la trompa es una forma especializada de tejido linfoide asociado a mucosa (MALT) $\left({ }^{14}\right)$.

\section{INFERTILIDAD MASCULINA INMUNOLÓGICA}

Diferentes tipos de anticuerpos pueden producirse de manera sistémica o localmente en el tracto reproductor masculino. Los anticuerpos pueden estar dirigidos a diferentes regiones de la superficie espermática, por lo que las respuestas serán variables. Se necesita concentraciones altas de anticuerpos en suero para que ingresen al líquido seminal. Sin embargo, la producción local de anticuerpos puede ser significativa.

La presencia de autoanticuerpos antiespermatozoides puede provocar dos mecanismos de acción: la interferencia con la habilidad del espermatozoide de llegar al sitio de fertilización o el impedimento para penetrar el 6vulo. El estudio de estos autoanticuerpos se realiza cuando los espermatozoides tienen un comportamiento inusual en el moco cervical, en la prueba post coital, o cuando el espermatozoide considerado normal no puede penetrar el moco periovulatorio in situ o in vitro, habiendose encontrado autoanticuerpos en un 15 por ciento $\left({ }^{15}\right)$.

Conociendo que las moléculas de timosina, especialmente la $T$ alfa $l$, puedan tener un rol en la capacitación del espermalozoide humano que lleva a la reacción acrosómica, la $\mathrm{T}$ alfa 1 podría terer aplicaciones clínicas en el diagnostico específico y en el tratamiento de la infertilidad masculina $\left({ }^{16}\right)$.

\section{ANTICUERPOS ANTIOVARIO}

Se ha comunicado hasta 70 por ciento de autoanticuerpos antiovario en mujeres con menopausia prematura quienes, además, muestran asociación con otros trastomos autoinmunes $\left({ }^{17}\right)$.
Se sugiere el empleo de terapia con glucocorticoides en dichas mujeres que desean concebir, aunque los resultados son pobres.

También, se ha hallado anticuerpos antiovario (AOA) en mujeres en las que tealiza fertilización in vitro (IVF). Se observa concentraciones altas de IgG AOA en mujeres que han tenido IVF y punciones foliculares repetidas, lo que parece correlacionarse con una disminución de las probabilidades de gestar. La producción de anticuerpos es debida al traumatismo ovárico y no a la estimulación hormonal. También, se encuentra una correlación negativa entre los niveles de IgM después de la punción. El número de oocitos y las concentraciones de IgA AOA en una primera muestra y de IgG o IgA AOA en una segunda muestra correlacionan con un menor número de oocitos después de la estimulación. No hay variación en las concentraciones de $\mathrm{AOA}$ en las mujeres que llegan a gestar $\left({ }^{18}\right)$.

Completaremos este acápite recordando que, últimamente, se ha expresado que el proposito del ovario es producir ovulos, lo que ocurre cíclicamente en intervalos mensuales. Pero, el control de dicha producción ovular es provista por ambos el sistema endo. crino y el inmunológico. O sea que, la producción exitosa de oocilos es el resultado de una comunicación sofisticada entre los dos sistemas, interacción necesaria para la continuación de las especjes $\left({ }^{19}\right)$.

\section{ABORTO RECURRENTE Y PÉRDIDAS FETALES REPETIDAS}

La existencia de un mecanismo de rechazo inmunológico natural que provoque un aborto esponiáneo ha sido demostrada en animales de experimentación, generalmente apareando especies distintas. Los úteros de los animales que rechazaron muestran infiltración linfocítica que denota là respuesta inmunológica local a los antígenos específicos de especie del trofoblasto.

En un grupo de pacientes con abortos recurrentes y muertes prematuras, se ha encontrado una lesion placentaria extensa consistente en trombosis e infartos $\left({ }^{\circ}\right)$ denominada "infarto del piso materno", con cantidades excesiyas de fibrina y grandes acúmulos de linfocitos y células plasmáticas alrededor de vellosidades denudadas, a pesar de no existir infección bacteriana o viral $\left({ }^{1}\right)$, y en las que hay presencia de anticuerpos antifosfolipidos. En el embarazo normal, los autoanticuerpos naturales no siguen el patrón estándar de inmunoglobulina (Ig) caracterizado por una disminución en sus niveles, a pesar de un pequeño incremento en su pro. duccion, lo que es excesivamente compensado por la vasodilatación del embarazo. Los anticuerpos antifosfolípidos tienen un discreto aumento durance la gestación -aunque pueden tener niveles anormalmente altos en el periodo periparto-, lo que resultarfa de un estímulo antigénico por el feto "parásito" (22).

Hoy se conoce que existen anticuerpos contra los fosfolípidos anticoagulante lúpico y anticardiolipina asociados a abortos recurrentes, muertes fetales, recardo de crecimiento fetal intauterino, parto pretermino, hipertensión inducida por el embarazo, desprendimiento prematuro de la placenta, trombosis arterial y venosa y el síndrome de serositjs postpartum (22.23.24.25.26.27). Estos anticuerpos desaparecen o disminuyen después del parto, para después aparecer con mayor activiodad en un nuevo embarazo $\left({ }^{2}\right)$. Un grupo de 
gestantes no presentan sintomatología, otras gestantes tiene historia de episodios de trombosis y otras sufren de lupus eritematoso sistémico (SLE). La lesión placentaria parece deberse a disminución de la producción de prostaciclina $\left(P G l_{2}\right)$ al bloquearse la liberación de ácido araquidónico por las células endoteliales ${ }^{0.28}$ ). Se considera también mayor adherencia de plaquetas $\left({ }^{9}\right)$, inhibición de la producción de prekalikreína $\left.{ }^{\circ 0}\right)$, deficiencia adquirida de proternas $\mathrm{C}$ y $\mathrm{S}$ y deficiencia de antitrombina III ('). Las mujeres con anticuerpos antifosfolípidos tienen más riesgo de desarrollar hipertensión inducida por el embarazo, con defecto de la $P G I_{2}$ vascular y hallazgos patológicos placentarios similares (26.2732.33). El exceso de anticuerpos antifosfolípidos puede tener efectos adversos sobre los procesos reproductivos mediante la intercepción de procesos de transducción de señal $\left({ }^{4}\right)$.

El anticoagulante lúpico es una $\operatorname{IgG}$ o IgM que interfiere con la activación del complejo activador de la protrombina. protrombina, factores Xa y V y calcio-, es decir, con la conversión de protrombina a trombina, adhiriéndose a la superficie fosfolípida del complejo activador de la protrombina e inhibiendo por competencia la adherencia de otros factores de coagulacion sobre la superficie del complejo. El tiempo de coagulación está prolongado. Las pacientes tienen mayor riesgo, no de hemorragia, sino de episodios de trombosis arteriolar y venosa $\left.{ }^{55}\right)$, la que puede ocasionar vasculopatía decidual e infarto placentario, que resultan en aborto recurrente o retardo de crecimiento fetal severo. La muerte fetal alcanza el 90 por ciento en los casos no tratados. Además, se asocia a hipertension, anemia hemolítica, neoplasias y algunos medicamentos, como hidralazina, clorpromazina y procainamida $\left({ }^{36}\right)$. El anticoagulante lúpico no parece tener mayor significado en la gestante normal $\left({ }^{37}\right)$. El diagnóstico se hace con el PTT activado (APTT) o el tiempo de veneno de víbora de Russell, el procedimiento de neutralización de plaquetas y la prueba de inhibición de tromboplastina tisular. El VDRL puede ser positivo. El tratamiento consiste en el empleo de la combinacion de $75 \mathrm{mg}$ de aspirina por dra, prednisona 20 á $80 \mathrm{mg}$ por dfa ( $\left.{ }^{3}\right)$ y heparina, con éxito de $80 \%\left({ }^{27}\right)$. El corticoide se inicia apenas diagnosticado el embarazo y aún antes de concebir, variando la dosis de prednisona de 40 a $60 \mathrm{mg} /$ día de acuerdo a la normalización del APTT, en 3 a 4 semanas o hasta las 24 semanas de embarazo, para después disminuir a dosis de mantenimiento de $10 \mathrm{mg} / \mathrm{d}$ ía por el resto del embarazo. La aspirina tiende a contrarrestar la tendencia plaquetaria de adherencia y agregación, inhibiendo la formación de tromboxano sin alterar la de $\mathrm{PGL}_{2}$. Se recomienda las dosis de 60 a $100 \mathrm{mg} / \mathrm{d}$ a durante todo el embarazo, sin haberse encontrado efectos negati. vos sobre el feto. La heparina también es administrada vía SC.

Las gestantes con anticuerpo anticardiolipina tienen manifestaciones similares a las que tienen anticoagulante lúpico, ocasionando abortos recurrentes y muertes fetales, episodios de trombosis y trombocitopenia $\left({ }^{3}\right)$. Alrededor del 20 al $30 \%$ de pacientes con SLE tienen anticuerpo a cardiolipina $\left({ }^{40}\right)$. Algunas pacientes tienen coexistencia de anticuerpo anticoagulante lúpico y anticuerpo anticardiolipina. El anticardiolipina subtipo IgG podrla predecir perdida fetal y trombosis $\left({ }^{41}\right)$. Se ha encontrado el anticoagulante lúpico en 2,7/1000 gestantes, mientras el anticardiolipina IgM en $22 / 1000$ gestantes ${ }^{23,32}$ ) o $1,25 \%$, pero sólo los títulos altos de anticuerpos tuvieron relación con las pérdidas fetales $\left({ }^{42}\right)$. También, se encuentra concentraciones altas de anticuerpos anticardiolipinas en pacientes con infecciones a HIV y citomegalovirus $\left({ }^{42}\right)$. El diagnóstico se realiza con radioinmunoensayo específico de fase sólida o por la prueba ELISA, El VDRL puede ser positivo. En relación a la terapia, los corticoides no tienen el mismo éxito que con los anticuerpos anticoagulantes lúpicos $\left({ }^{17 * 3}\right)$, por lo que se usa dosis altas de prednisona. Debido a los efectos secundarios, otros autores prefieren el uso de heparina, sola o en combinación con aspirina ( ${ }^{4+45}$ ). La heparina reducirfa los infartos placentarios, aunque hay más probabilidades de parto pretérmino y de cesáreas ( ${ }^{46}$ ). Se la utiliza desde el inicio del embarazo hasta que empieze el parto 624 a 48 horas antes de la cesárea, 7500 unidades SC cada 12 horas en el primer trimestre y 10000 a 12000 unidades cada 12 horas en el resto del embarazo ( ${ }^{42}$ ). Aparte de la terapia indicada, se usa la azathioprina $\left({ }^{47}\right)$ y las IgG intravenosas $\left({ }^{48}\right)$.

También, se ha encontrado mayor incidencia de antígenos de histocompatibilidad materno-paterno (HLA) en parejas con aborto recurrente que en la población general. La estimulación apropiada de anticuerpos bloqueadores no ocurrina en las etapas tempranas del embarazo y el feto podría ser rechazado. En ellas se ha recomendado la transfusion de leucocitos y se estudia la posibilidad de vacunas.

\section{HIPERTENSION INDUCIDA POR EL EMBARAZO (HIE)}

Desde tiempo atrás, es motivo de atención en el embarazo el cuadro caracterizado por hipertensión, acompanado no siempre por edema y proteinuria, convulsiones y/o coma, y que hoy conocemos parece tener su origen en una alteración del endotelio vascular y en una placentación anormal. Ocurre en alrededor de 2 al $10 \%$ de los embarazos en nuestro medio, siendo causa importante de muerte materna y perinatal, asi como de retardo de crecimiento intrauterino. Es más frecuente en la primigesta, cuando hay historia familiar de bipertension y en la enfermedad del trofoblasto. Habria ur factor hereditario recesivo dependiente del genotipo materio. También ha sido asociada a la trisomía 13 fetal $\left({ }^{49}\right)$.

Se conoce que en el embarazo normal hay un mecanismo de tolerancia inmunologica que impide el rechazo del feto, a pesar de existir antígenos patemos extraños a la madre. Dicho mecanismo consistirfa en la formación de los anticuerpos bloqueadores $\left({ }^{50.51}\right)$, con disminución de la función de las células $\mathrm{T}$ de ayuda $\left({ }^{50}\right)$, así como en el número de las células $\mathrm{T}$ de ayuda y de las supresoras ${ }^{(22)}$. No se ha encontrado variaciones en la formula blanca, en los monocitos, porcentaje de células $\mathrm{T}(\mathrm{OKT} 3+)$ o en la relación de células de ayuda a células supresoras (OKT4/OKT8); tampoco hay variaciones de los niveles de IgG, IgM, IgA e $\operatorname{IgD}^{(53)}$, aunque podría aumentar levemente en la preeclampsia severa. Pero, sí se ha encontrado aumento del porcentaje de células de ayuda OKT4+, lo que indicaría aumento de monocitos $\left({ }^{54}\right)$. Existe depósito de com- 
piejos inmunes y componentes de complemento en la placenta, piel, hrgado y glomérulo en pacientes pre-eclámpticas, lo que haŕa pensar que dichas modificaciones se debieran a las lesiones patologicas de la vasculatura placentaria $\left({ }^{53}\right)$.

Se ha informado sobre niveles anormales de autoanticuerpos a antígenos de trofoblasto, placenta y riñón, así como anticuerpos antivasculares ( ${ }^{15}$ ) y contra linfocitos y laminina $\left(^{53}\right)$.

Por otro lado, la placentación se acompaña de la invasión de las paredes de las arterias espirales por células trofoblásticas, degeneración de las capas musculares de las paredes arteriales y formación de material fibrinoide, lo que resulta en que los antígenos fetales foráneos expresados en dicho trofoblasto se exponen directamente a la sangre matema que contiene factores inmunes celulares y humorales, por lo que debe existir un mecanismo de tolerancia inmunologica $\left(^{56}\right)$.

Hay varias comunicaciones que señalan que la hipertensión inducida por el embarazo es un trastorno inmunológico, en el que la respuesta inmunologica materna ante el injerto fetoplacentario es anormal, con falla de los anticuerpos bloqueadores. Se ha asociado esta posibilidad a la primigravidez $\left({ }^{57}\right)$, al aumento de la masa trofoblástica, a embarazos con pareja diferente $\left({ }^{8}\right)$, embarazo después de donación de oocitos $\left({ }^{59}\right)$, embarazo con preservativo $(2,4$ veces más que con otros anticonceptivos) $\left({ }^{60}\right)$, a menor frecuencia de exposiciones a los espermatozoides, soltería $\left({ }^{60}\right)$. La incidencia de HIE podría disminuir en el futuro embarazo con la misma pareja si no hubo hipertensión en el embarazo anterior ( ${ }^{61.62}$ ). También, si hubo aborto previo, lo cual no siempre ha sido confirmado (c).

Aunque no se ha verificado el incremento de la incompatibilidad HLA, sí hay zumento aparente de la doble homozigocidad para antígenos HLA (HLA-A y HLA-B) en la HIE severa ( ${ }^{3}$ ). Otros estudios encuentran que la presencia del antígeno HLA-DR4 se asocia con mayor incidencia de preeclampsia $\left({ }^{\leftrightarrow}\right)$, lo cual tampoco ha sido corroborado.

Ya hemos descrito que la galactosa alfa 1-3 galactosa (Gal alfa $1-3 \mathrm{Gal}$ ) tiene expresión en las células trofoblásticas humanas en diferentes etapas de la implantación de la placenta y en varias condiciones asociadas al embarazo. No se encuentra Gal alfa $1-3 \mathrm{Gal}$ en la superficie celular de las arterias espirales de mujeres preeclámpticas. Pero, los anticuerpos anti-Gal están aumentados en el suero de pre-eclámpticas y eclámpticas. La unión de anticuerpos anti-Gal maternos al trofoblasto podŕa contribuir a limitar la invasión trofoblástica y participar en el control inmunológico de la implantación (ss).

\section{DIABETES Y EMBARAZO}

En la gestante diabética, hay sobreposición de las anormalidades inmunológicas de la diabetes y las modificaciones inmunologicas que ocurren normalmente en el embarazo. Las células mononucleares de sangre periférica (PBMC) de madres normales y con diabetes Tipo I muestran aumento de CD8+ y disminución de células CD4+, comparadas con las células mononucleares respectivas del cordón (CBMC). Además, las PBMC Tipo I muestran un menor número de células CD3+ DR+ "activadas" y un mayor número de células CD8+ CD25+ con respecto a la mujer normal, lo que puede reflejar el patrón disregulatorio debido a la condición autoimmune. Las CBMC Tipo I muestran un gran aumento en el número de células CD4+ Leu8+, una subpoblación celular caracterizada por actividad inhibitoria. Con respecto a la liberación de linfoquina en cultivos, la diabetes tipo I parece estar asociada con la sobreproducción de ILl e IL6, aunque el aumento del segundo es menos evidente en cultivos de CBMC. Como tal, el embarazo en la diabélica está asociado con alteraciones mayores de la inmunidad mediada por células que lleva a un estado de inmunodepresión. El estado inmunológico matemo influencia la inmunidad fetal, pues hay aumento en el número de células regulatorias y alteración del patrón de producción de linfoquina (IL1 e IL6) por los linfocitos derivados de CBMC de diabéticas, lo que es un reflejo de las características PMNC maternas ( $\left.{ }^{6}\right)$.

\section{ISOINMUNIZACIÓN RH}

Desde 1901 se ha identificado más de 20 diferentes sistemas de grupo sanguíneo. El sistema $\mathrm{ABO}$ fue el primero en ser descrito y continúa como el más significativo clínicamente por las transfusiones de sangre y el transplante de órganos. Los antígenos $\mathrm{ABO}$ son antígenos celulares que consistentemente producen un anticuerpo potente y natural que circula en el plasma de individuos sanos. Los antígenos $A B O$ se expresan en la mayoría de células sanguíneas, órganos y tejidos y en la mayoría de fluídos corporales. La expresión de los antígenos resulta de la interacción de varios genes separados, pero relacionados, los genes $\mathrm{ABO}, \mathrm{H} \mathrm{y}$ Secretor (Se). La especificidad de grupo sanguíneo depende de la herencia de los genes $\mathrm{ABO}$ y $\mathrm{H}$ y la subsiguiente expresión de estos antígenos en los hematíes.

El antígeno "D" o Rho es, después de los antígenos ABO, el antf́geno de grupo sanguíneo más significativo clínicamente. Pertenece al Sistema $\mathrm{Rh}$, que consiste de un 1 río de genes tan unidos que se les hereda como paquete. Los antígenos son una parte integral de la membrana del hematie, a la que le dan estabilidad cuando existen. Su ausencia disminuye la sobrevida del hematíe. Los anticuerpos $\mathrm{Rh}$ son anticuerpos inmunes que requieren un estímulo y pueden causar complicaciones significativas en el feto y recién nacido $\left({ }^{67}\right)$.

Mientras que la enfermedad hemolítica por incompatibilidad ABO es rara -debido a que la mayora de la isohemaglutininas son anticuerpos IgM que no cruzan la bartera placentaria-, en el caso del factor $R h$, los anticuerpos anti-D son inicialmente IgM, pero, ante la persistencia de la antigenicidad, se producen anticuerpos IgG que sí cruzan la placenta y ocasionan la eritroblastosis fetal.

La fisiopatología consiste en que un feto Rh positivo ocasiona la formación de anticuerpos anti-Rh en la madre Rh negativa (quied tiene ausencia del factor $R h$ ). En la primera inmunización, la respuesta inmunológica de la madre $R$ h negativa es lenta y no se detecta anticuerpos anti-D hasta 6 semanas a 6 meses después de la invasión del factor foráneo. Es por eso que este primer niño no será afectado, salvo muy raras excepciones. Pero, los anticuerpos formados en la madre afectarán a una siguiente gestación con feto Rh positivo. Los anticuerpos anti-Rh atacan los hematies fetales $\mathrm{e}$ 
inician su destrucción. Esta destrucción será mayor conforme haya mayor cantidad de anticuerpos, pudiendo provocar anemia fetal severa, hidropesia, hepato- y esplenomegalia, entre otros; la placenta se hipertrofia y tiene mayor vascularización y el líquido amniotico aumenta en volumen y varía su coloración hacia la ictericia por la destrucción de los hematíes fetales.

Sólo uno de cada 10 niños es afectado. Los hematíes felales son detectados en circulación materna desde las 8 semanas de embarazo y su ingreso aumenta conforme avanza el embarazo. Las hemorragias transplacentarias son comunes en la gestación, pero son pequeñas y sólo en 1 por ciento es mayor de $0,25 \mathrm{~mL}$ en el tercer trimestre. $O$ sea, la barrera placentaria no es completamente infranqueable y habria una progresiva disminución de esa aptitud durante el embarazo. La hemorragia feto-matema es varias veces mayor en el parto y, principalmente, con ciertas maniobrä shstétricas. La mayor parte de las sensibilizaciones ocurre en esta eta$\mathrm{pa}$, cuando una uansfusión de $560100,1 \mathrm{~mL}$ de sangre $\mathrm{Rh}$ incompatible puede ocasionar la sensibilización. En los casos de trauma obstétrico o desprendimiento prematuro de la placenta, la transfusión es mucho más grande aún.

La incompatibilidad $A B O$ da un grado de protección al feto con incompatibilidad $\mathrm{Rh}$, -salvo cuando la madre ya ha sido inmunizada anteriormente-, disminuyendo la posibilidad de isoinmunización $\mathrm{Rh}$ alrededor de 17 veces.

Se cree que los casos de inmunización al factor Rh en mujeres primigestas que jamás recibieron transfusión, sean debidas a las repetidas pequeñas hemorragias que ocurren durante el embarazo, o a transfusiones matemo-fetales in utero.

La prevención de la isoinmunización $R$ h consiste en administrar anticuerpos anti-D a la madre en el periodo puerperal, acostumbrándose por protocolo a indicarlo dentro de las primeras 78 horas del parto. Pero, como se ha visto más arriba, y debido a la respuesta inmunológica lenta, se puede dar la vacuna hasta varias semanas después. Los productos obtenidos en el mercado tienen 120 y $150 \mu \mathrm{de}$ anticuerpo anti-D. La dosis será incrementada de acuerdo a la hemorragia feto-matema que hubiera ocurrido, lo cual se puede establecer estudiando la cantidad de hematfes fetales en sangre materna en la lámina con celdas de Kleihauer. Al administrarse la dosis respectiva, este anticuerpo cubriría los determinantes antigénicos correspondientes de las células fetales y prevendrían su expresión inmunologica, evitando la formación de anticuerpos en sangre materna. La vacuna es también empleada durante el embarazo y luego de un aborto, sin que haya aún consenso sobre su validez real.

\section{HIDROPESÍA FETAL}

Conocemos que la transferencia de hematíes y plaquetas fetales a la circulación materna puede estimular una respuesta imune consistente en la producción de inmunoglobulina que puede atravesar la placenta. De manera similar, el pasaje de células sanguíneas matemas (stem) a un feto inmunologicamente incompetente puede teoricamente producir una enfermedad injerto-versus-buésped. La sensibilización materna a antígenos de los hematues, tales como los D y Kell, puede ocasionar anemia, hidropesfa y muerte de un feto incompatible. La evaluación de estos embarazos consiste en análisis seriados de bilirrubina en líquido amniótico, asi como muestras sanguíneas de cordón umbilical en circunstancias especiales. Ni la ecografía ni la velocimetría Doppler pueden predecir con precisión el hematocrito fetal. En los fetos hidrópicos, el tratamiento preferencial es la transfusión intravascular. La sobrevivencia perinatal en los fetos no hidrópicos es similar con transfusion intravascular o intraperiloneal. La trombocitopenia isoinmune fetal es generalmente el resultado de la sensibilización materna al antígeno PIA1. No hay riesgo mayor de hemorragia intracranial, tanto anteparto como durante el trabajo de parto y el parto. En las muestras de sangre de cordón umbilical obtenidas de fetos a término se puede determinar la cantidad de plaquetas y la necesidad de transfusión de plaquetas, así como puede ayudar en decidir la ruta más apropriada para el parto ${ }^{\left({ }^{8}\right)}$.

\section{ENFERMEDADES DEL TEJIDO CONJUNTIVO VASCULAR Y EMBARAZO}

Entre las enfermedades del tejido conjuntivo vascular que interactían con el embarazo, destaca el lupus eritematoso sistémico (LES), enfermedad con predisposición genética que afecta a la mujer 9:1 con respecto al hombre, especialmente en la etapa reproductiva, por lo que se se postula la influencia que podrfa tener la producción grande de estrógenos (69.70.71). Aunque la enfermedad es diagnosticada en la mayoría de veces en la mujer no gestante, en un pequeño porcentaje se hace el diagnostico durante el embarazo y en un $15 \%$ cuando hay historia de pérdidas fetales recurrentes. Habrá infertilidad cuando exista insuficiencia renal severa, con creatinina mayor de $3 \mathrm{mg} / \mathrm{dL}$. Es característico el hallazgo de anticuerpos atípicos, principalmente antinucleares (DNA de filamento doble y único, desoxiribonucleoproterna, ribonucleoproteína, antígeno SM, antígenos carbohidrato. proteicos), pero también contra estructuras citoplasmáticas (linfocitos B y T, plaquetas, hematíes y leucocitos) y moléculas antigénicas, como la $\gamma$-globulina, cardiolipina y $\mathrm{Rh}_{0}\left({ }^{72}\right)$. En los pacientes con LES se ha encontrado aumento de antígenos de lucocitos humanos (HLA) de las regiones DRw2 y DRw3 (3). Se cree que la enfermedad serfa causada por una infección viral en una persona predispuesta $\left({ }^{4}\right)$

Se sospecha el LES cuando una mujer en edad reproductiva manifesta glomerulonefritis, síndrome nefrótico, anemia hemolítica, leucopenia o trombocitopenia. Se buscará anticuerpos anticoagulante lúpico (+5 a 15\%) y anticardiolipina, anticuerpos antinucleares $(+98 \%)$, células LE $(+80 \%)$, anemia, leucopenia y se hara la interconsulta con el internista o reumatólogo. También se encuentra niveles de $\mathrm{C} 3$ y $\mathrm{C} 4$ disminuídos y aumento de gamma globulina (75\%), prueba de artritis reumatoide positiva (15 a 20\%) y serología falsa positiva.

Con respecto al complemento, en el embarazo normal los niveles de $\mathrm{C} 3, \mathrm{C} 4$ y $\mathrm{CH} 50$ séricos aumentan gradualmente, mientras que en el LES disminuyen o por disminución en su síntesis o por disminución de su activacion, ya que hay niveles normales del 
complejo inhibidor $\mathrm{Cls}-\mathrm{Cl}$. Durante el embarazo normal puede haber incremento de productos de fragmentación de complemento, tales como de C3a plasmático, lo que se correlaciona positivamente con elevaciones de C3. En los embarazos complicados por SLE, los aumentos de C3a son a menudo acompañados por una disminución de $\mathrm{C} 3$ total y de $\mathrm{CH} 50$. En una minoría de pacientes sin SLE, se ha asociado la preeclampsia con elevaciones de una variedad de productos de fracciones de complemento, como $\mathbf{B a}$, C3a, C4d, SC5b-9, indicando activación de las cascadas clásica y altema. Los niveles de $\mathrm{CH} 50$ tienden a permanecer normales en estas pacientes. En contraste, las elevaciones de productos de fraccionamiento del complemento frecuentemente acompañan las exacerbaciones de la LES. Una relación alta de CH50/Ba podría diferenciar las pacientes con preeclampsia de aquellas con LES activa. Y la disminución de $\mathrm{C} 3, \mathrm{C} 4$ o $\mathrm{CH} 50$ acompañada de elevaciones de los productos de fragmentación de complemento parecen diferenciar una exacerbación de SLE de otras complicaciones del embarazo $\left({ }^{5}\right)$.

Si la mujer no ha tenido enfermedad aguda por más de 6 meses antes del embarazo, el LES no recidivaria durante el embarazo y las probabilidades de un recién nacido vivo es de $90 \%$. Las complicaciones del embarazo son varias, principalmente nefritis -en cualquier momento de la gestacion- y/o hipertensión inducida por el embarazo (HIE), aborto espontáneo, abortos recurrentes, muerte fetal, parto pre término, retardo de crecimiento fetal intrauterino (RCIU) ( ${ }^{3}$ ). La enfermedad puede exacerbarse después de un aborto inducido o después del embarazo ectópico y la enfermedad del trofoblasto. El compromiso renal aumenta el aborto recurrente. La idea que la enfermedad recurre con más frecuencia en el puerperio está en revisión ${ }^{0.76}$ ). Sin embargo, la mujer puede morir durante el embarazo (1 a $2 \%$ ) y hasta dos años después, principalmente si tiene complicaciones renales y del sistema nervioso central $\left({ }^{\circ}\right)$. La presencia de HIE y compromiso renal puede ser diffcil de diferenciar y el manejo considerará tanto el bienestar materno como el fetal; la mortalidad perinatal ante ambas complicaciones puede llegar al $20 \%\left({ }^{76}\right)$. Se emplea la hemodiálisis para corregir la insuficiencia renal durante el embarazo. Mujeres con transplante renal $(7)$ y LES requieren una evaluación pre concepcional de las funciones renal, hepática y hematológica, pues hay incidencia alta de HIE severa, infección urinaria, hidronefrosis, prematuridad y sufrimiento fetal $\left({ }^{(0.78}\right)$; se les recomendará gestar sólo si el LES y la función renal están estables.

Con respecto al feto, es importante el RCIU -referida a vasculitis placentaria ( $\left.{ }^{79}\right)$-, mas bien de tipo simétrico, con riesgo de secuelas neurológicas, puede ser por el uso de corticoides. Se encuentra células LE en la circulación umbilical y el neonato puede tener alteraciones de la conducción cardíaca y hematológicas $(99.80)$.

Para la exacerbación del LES durante el embarazo, se usa la prednisona $60 \mathrm{mg} / \mathrm{d}$ ́a por 2 a 3 semanas, disminuyendo la dosis despues hasta retirarla. Se usará dosis mayores cuando hay compromiso del sistema nervioso central con convulsiones o psicosis. En la nefritis lúpica, el tratamiento con prednisona es similar, con 40 a $60 \mathrm{mg} / \mathrm{d} / \mathrm{a}$, aunque a veces hay que añadir azatioprina 1 a 2 $\mathrm{mg} / \mathrm{kg} / \mathrm{d}$ la o ciclofosfamida ('). Se recomienda usar $100 \mathrm{mg}$ de hidrocortisona EV en tres dosis alrededor del parto, pero no en el puerperio, salvo exacerbaciones. Evitar la lactancia en mujeres que reciban inmunosupresores. La anticoncepción es mandatoria, incluyendo la definitiva -preferiblemente en el esposo-, el método de barrera y, con observación cercana, el dispositivo intrauterino.

La artritis reumatoide (AR) se inicia con artritis simétrica de las articulaciones pequeñas, muñecas y manos, primero intermitente y luego persistentemente y acompañada de inflamación. Se confirma la enfermedad con títulos de factor reumatoide 1:80 6 mayor, pudiendo ser los anticuerpos antinucleares positivos. La prueba más útil es la artrocentesis, encontrándose un líquido acuoso fluído, negativo para bacterias y cristales, con cuenta de luecocitos de 2000 a $50000 / \mathrm{mL}$. Se ha hallado que la fecundidad de las mujeres que luego desarrollarán AR es menor que las que no tendrán la enfermedad ( $\left.{ }^{81}\right)$. El $75 \%$ de las gestantes tendrán remisión del cuadro en el primer trimestre, usándose prednisona $5 \mathrm{mg} /$ día y dosis baja de salicilatos de $3 \mathrm{~g} / \mathrm{d}$ á. Se puede administrar corticoides intraarticularmente. Se recomendará el descanso y no usar antimaláricos, -como la cloroquina-, las sales de oro, la penicilamina durante la gestación. Durante el parto puede ocurrir compresion de la médula cervical y el compromiso de la pelvis por la artritis puede dificultar el parto vaginal.

El escleroderma o esclerosis sistémica progresiva se caracteriza por el fenómeno Raynaud, mialgias difusas, artritis de las manos y engrosamiento progresivo y simétrico de la piel de las extremidades. Luego, viene el compromiso de los aparatos renal y gastrointestinal, sufriendo de disfagia e hipertensión maligna. Incrementa el riesgo de abortos, trabajo de parto pre término, distocia de partes blandas, pobre cicatrizacion de incisiones y epísiotomía y mortalidad materna por insuficiencia renal, por HIE y eclampsia.

La dermatomiositis compromete piel y músculo, asociándose con malignidad en uno de cada 7 casos. Los glucocorticoides pudieran mejorar el cuadro, siendo la mortalidad perinatal elevada. La poliarteritis nodosa es una vasculitis necrotizante de arterias pequeñas y medianas, que se asocia en el embarazo con HIE e insuficiencia renal, pudiendo ocurrir la muerte materna. Se usa in munosupresores.

El sindrome de Marfan es un trastorno hereditario autosómico dominante del tejido conectivo, con debilidad de la pared aótica, pudiendo ocurrir la disección de la pared mediana de la aorta descendente durante el embarazo, que ocaciona la muerte materna. La cesárea no protege a la madre de esta complicación. El sindrome de Ehlers-Danlos se caracteriza por hiperelasticidad de la piel, con tendencia a la rotura arterial y muerte, así como hipervolemia. Las espondiloartropatlas pueden ser diferenciadas de la artritis reumatoide (AR) por ausencia del factor reumatoide; no varía durante el embarazo, siendo su tratamiento similar a la de la $A R$, con salicilatos. La artritis psoriásicí puede ocasionalmente necesitar tratamiento con methotrexate. 


\section{PÚRPURA TROMBOCITOPÉNICA AUTOINMUNE Y EMBARAZO}

La púrpura trombocitopénica autoinmune (PTA) consiste en la destrucción de las plaquetas por autoanticuerpos IgG, entidad que afecta tres veces más a la mujer que al hombre y que se manifiesta preferentemente en la segunớa a cuarta década de la vida, por lo que puede complicarse con el embarazo en 1 a $2 / 10,000$ casos $\left({ }^{82}\right)$. Las plaquetas tendrían en su membrana externa un antigeno indeterminado que ocasionaría la elaboración de anticuerpos por el bazo, el hígado y la médula ósea. También, podría depositarse complemento en la misma superficie plaquetaria, lo que atraería macrófagos por quimiotaxis (3) y sería factor importante en la trombocitopenia periparto. Ocurrida la unión del anticuerpo IgG y/o complemento sobre la plaqueta, los macrófagos la fagocitarían principalmente en el bazo. Así mismo, los anticuerpos unidos a megacariocitos en la médula ósea impiden una producción suficiente de plaquetas ( ${ }^{(4)}$ ). El diagnóstico se hace detectando trombocitopenia (plaquetas $<150,000$ ), aglomeracion de plaquetas al examen de sangre periférica, presencia de megatrombocitos con muchos gránulos secretorios, aspiración de médula ósea si la cuenta de plaquetas es $<50,000 / \mathrm{mL}$. Se descartará infección viral reciente, radiación, infiltración por leucemia o linfoma, deficiencia vitamínica o de folato, síndrome HELLP, coagulación intravascular diseminada, púrpura trombocitopénica trombótica, lupus eritematoso sistémico ${ }^{82}$ ). No parece que el embarazo exacerba la PTA. En los casos que se complican con trombocitopenia, algunas requieren corticoides $y$, raramente, esplenectomía, temitiendo el cuadro post parto. Las gestantes pueden presentar epistaxis, hemorragia retiniana o gingival, hemorragia puerperal en $26 \%$ ( ${ }^{(4)}$ ), sangrado de episiotomía o laceraciones y. raramente, muerte materna ${ }^{86}$ ). El IgG antiplaqueta cruza la barrera placentaria y puede ocasionar alrededor de $20 \%$ de mortalidad perinatal $\left({ }^{8} 8.6788\right)$, principalmente por hemorragia intracerebral, por lo que se recomienda atender el parto por cesárea en fetos que en muestras percutáneas de cordón -mejor que de cuero cabeiludotengan $<50,000$ plaquetas $/ \mathrm{mL}$, lo que no salva de morbimortalidad al recién nacido. Ni la cuenta de plaquetas ni los niveles de anticuerpos antiplaquetarios maternos tendrían correlacion directa con la trombocitopenia del neonato.

El tratamiento de la PTA es con corticosteroides orales, que mejoraria la producción de plaquetas por la médula ósea. Se administra prednisona 1,0 a $1,5 \mathrm{mg} / \mathrm{kg} / \mathrm{d}$ fa hasta que la producción de plaquetas se normalize, lo que ocurre en la mitad de casos, disminuyéndose luego el corticoide gradualmente. Es controvertida la administración de 60mg de prednisona diario durante las 3 a 4 últimas semanas del embarazo para prevenir la trombocitopenia neonatal $\left({ }^{89}\right)$. La prednisona es inactivada por la placenta y s6́lo $10 \%$ llega al feto; cerca de $50 \%$ de la dexametasona es inactivada por la placenta $\left({ }^{\circ}\right)$. Si en pleno tratamiento con prednisona se iniciara el parto, se administra hidrocortisona $100 \mathrm{mg}$ EV cada 8 horas durante el trabajo de parto, $100 \mathrm{mg}$ EV cada 12 horas el segundo día y, luego, se continúa por vía oral $\left({ }^{(2)}\right)$. Si la paciente no responde a los corticoides orales, se administra globulina (IgG) hiperinmune EV, $400 \mathrm{mg} / \mathrm{kg} / \mathrm{d}$ ía por 5 días consecutivos, la que bloquearía los receptores $\mathrm{Fc}$ de los macrófagos del sistema reticuloendotelial $\left({ }^{9}\right)$. La duración del tratamiento puede ser de 4 a 5 semanas, por lo que se administra al final del embarazo, sin que impida siempre la trombocitopenia neonatal $\left({ }^{92}\right)$. Su costo es muy alıo, por lo que se la está reemplazando por la inmunoglobulina rhesus (RhIg) que, al sensibilizar los hematies, bloquea el sistema reticuloendotelial $\left({ }^{82.93}\right)$.

Si no hubiera respuesta con los tratamientos anteriores, se recurre a la esplenectomía, exitosa en el 70\%, normalizándose las plaquetas en dos semanas. La esplenectomía es más sencilla quirúrgicamente antes del tercer trimestre del embarazo, por lo que al final de la gestación se sugiere la IgG EV, inducción del feto al adquirir madurez y esplenectomía en el puerperio. No se recomienda la cesárea más esplenectomía, salvo que se indique la cesárea por estrictas razones obstétricas. Y si no mejorara la paciente con la esplenectomía, se usa el darazol $200 \mathrm{mg} \mathrm{3-4/dra,} \mathrm{que}$ disminuiŕa el número de receptores $F C$ en los macrofagos, con repuesta en 6 a 8 semanas $\left({ }^{4}\right)$ y que pudiera ser androgenizante. También, se ha utilizado plasmaféresis y agentes quimioterapéticos, como ciclofosfamida, azathioprina y alcaloides de la vinca, que han sido asociados a retardo de crecimiento fetal, malformaciones congénitas menores y leucopenia y trombocitopenia neonatal $\left({ }^{55.96 .97}\right)$.

\section{TRANSPLANTE DE ÓRGANOS Y DROGAS INMUNOSUPRESORAS DURANTE EL EMBARAZO}

Como cada vez se realiza un número mayor de transplantes en el mundo y en nuestro país, con sobrevida de la mujer y la probabilidad futura de embarazo, es importante recordar qué puede ocurir con el empleo de drogas inmunosupresoras durante la gestación. La mayor experiencia es con transplantes del riñon, pero en la literatura se encuentra ahora mujeres con transplantes de médula osea, hígado, corazon, corazón-pulmón que luego gestaron ( $\left.{ }^{8}\right)$, lo que trae nuevas experiencias al ginecoobstetra. Las drogas más empleadas durante el embarazo son los corticoesteroides, la azachioprina, la ciclosporina. Mientras con la prednisona no se ha encontrado incremento de malformaciones, con la azathioprina sí habrla un pequeño aumento de estenosis pulmonar, ductus arteriosus, hernias inguinales y se cree pudiera tener efectos a largo plazo en la fertilidad del recién nacido. Con la ciclosporina, aumentan las infecciones virales en la mujer, hay hipertricosis y anemia; existe pasaje selectivo por placenta y leche matema, pero sin aumento de alteraciones cromosómicas. Habría un incremento de la posibilidad de neoplasia cervical ( $\left.{ }^{\$ 8}\right)$.

Una de cada 50 mujeres transplantadas renales gesta $(99)$. siendo las complicaciones la hipertensión, proteinuria, muerte fetal intrauterina, retardo de crecimiento fetal, prematuridad, insuficiencia renal, rechazo del injerto, infecciones urinarias, muerte materna $\left(^{8.100}\right.$ ). Los resultados son mejores cuando el injerto es con rinín de donante vivo, recomendándose gestar cuando la función renal es satisfactoria, con creatinina menor de $1,4 \mathrm{mg} / \mathrm{dL}\left({ }^{(10)}\right)$. Vi- 
gilar la hidronefrosis con ecografía o urografía excretoria. La hipertensión, el dolor y el edema del injerto y la fiebre pueden indicar rechazo del injerto, debiendo usarse altas dosis de corticoides $y$, eventualmente, terminar el embarazo. No se observa incremen10 en malformaciones fetales $\left({ }^{10 \hat{2}}\right)$.

El transplante de médula ósea se realiza en pacientes con trastomos hematológicos malignos y no malignos, tales coma leucemia o anemia aplásica. Previamente, se usa dosis altas de ciclofosfamida con o sin irradiación, lo que pudiera alterar la función ovárica, especialmente en mujeres mayores de 25 años. Se informa que los niños que nacen de estas mujeres no tienen mayor riesgo de malformaciones congénitas ${ }^{(98)}$.

Hay muy pocos casos de gestaciones en transplantadas hepáticas, observándose retardo de crecimiento fetal, así como en transplantadas cardíacas o cardio-pulmonares $\left(^{98.103}\right.$ ).

La consejería antes del embarazo es importante en las mujeres transplantadas, evaluándose las probabilidades de transmitir a sus hijos los problemas que originaron el transplante, así como la posible sobrevivencia después del transplante, lo que puede signifjcar que deje en la orfandad a un niño muy pequeño. También es importante que la mujer no abandone las drogas inmunosupresoras. La madre puede tener más probabilidades de infecciones virales, especialmente a citomegalovirus y hepatitis $B$, los que pueden infectar al recién nacido. Se recomienda no gestar antes de 18 a 24 meses después del transplante, siendo el control pre natal efectuado por un equipo multidisciplinario, incluyendo al psicólogo y el servicio social $\left({ }^{102}\right)$. Tendrá exámenes de laboratorio diversos y periodicos, ecografías obstétricas y pruebas de bienestar fetal. Se recomienda el parto vaginal, evitar muchos exámenes pélvicos y la amniorrexis, la atención inmediata de la rotura prematura de membranas, el empleo de profilaxis antibiótica en la cesárea, el tratamiento agresivo de la endometritis puerperal. El recién nacido tendrá un examen meticuloso, sugiriéndose el análisis cromosómico. Evitar la lactancia matema, por el empleo de las drogas inmunosupresivas $\left({ }^{98}\right)$.

\section{INFECCIONES DURANTE EL EMBARAZO}

No se ha encontrado una resistencia menor de la mujer embarazada a las infecciones bacterianas ni a los virus RNA. Sin embargo, las infecciones a virus DNA, especialmente a citomegalovirus y papiloma virus, serían algo más severas que en la no gestante $\left({ }^{10-}\right)$. También, lo serían las infecciones por malaria $\left({ }^{104,105}\right)$, loxoplasma, amebas, giardia, tripanosomas, coccydioidomicosis $\left({ }^{106}\right)$, candidiasis, Listeria. Por lo que, el ginecoobstetra que atiende a una gestante debe tener conocimiento básico de las defensas del huesped y las alteraciones normales de dichas defensas durante el embarazo y conocer la resistencia bacteriana a los agentes antimicrobianos, con el objeto de determinar apropriadamente la localización, el microorganismo y la droga a prescribir $\left({ }^{107}\right)$.

\section{INMUNIDAD Y PARTO PRETÉRMINO}

Nos ocupamos anteriormente sobre las posibilidades como el feto evita ser rechazado por la madre $\left({ }^{108}\right)$. Por otro lado, se consi- dera que el mecanismo de protección sea mas bien similar a lo que acurre con las neoplasias malignas. Las células malignas activan mecanismos inmunosupresores que favorecen su presencia y multiplicación. De manera similar, el trofoblasto murino induce el acúmulo en la decidua de células supresoras naturales que no son linfocitos $T$, al liberar el factor $B$ de crecimiento tranformador (TGFB), que suprime la inmunidad celular y humoral y se une a las células matadoras linfocito-activadas (células LAK) e inhibe su inducción por interlequina 2 ([L-2) $\left({ }^{109}\right)$. Las células trofoblásticas son resistentes a la destrucción por las células matadoras naturales (NK), aún después de la activación de las últimas por gamma interferón (IFN-gamma) y por los linfocitos $T$ citotoxicos (CTLs) antígeno-específicos. Pero, en presencia de niveles alcos de IL-2, las células NK se convierten en células LAK y lisan las células trofoblásticas. Algo similar ocurre con otras citoquinas, como el factor alfa de necrosis de tumor (TNF alfa), el IFN-gamma y la IL1. cuando se les induce antes de que ocurra la producción de TGFB. Secundariamente, hay destrucción de las células que expresan el antígeno paterno en la superficie fetal por CTLs antígeno-especificos.

La infección bacteriana puede sobrepasar la inmunosupresión inducida por tumor y ocasionar un ataque inmunológico sobre las células tumorales al activar los macrófagos e inducir células LAK y CTLs con IL-2 activada. Por lo que la repuesta immune mediada por células -y no la humoral-sería valiosa para la sobrevida fetal. Los macrofagos tienen presencia importante en la decidua y en la placenta, mientras los linfocitos $\mathrm{T}$ y $\mathrm{B}$ tienen niveles menores. Los macrofagos producen proteasas y colagenasas que, por fagocitosis y eliminación del debris celular, facilitan la acomodación del embrión, así como limitan la respuesta inmune a antígenos propios y elimiran complejos inmunes potencialmente dañinos de la circulación. Pero, al alterar su función ante infecciones externas o activación del sistema inmune, esta protección al embarazo sería sobrepasada.

La interleuquina-1 (IL-1) ha sido implicada en el mecanismo del parto cuando existe infeccion. Mientras que la IL-1 alfa y la IL-1 beta no son detectables en el líquido amniótico de gestantes en el segundo trimestre, la IL-1 tiene niveles altos en pacientes con rotura prematura de membranas pretérmino, durante el trabajo de parto y cuando hay cultivos de líquido amniótico positivos $\left({ }^{110}\right)$.

Los macrófagos residentes en ciertos tejidos producen prostaglandina $\mathrm{E}_{2}\left(\mathrm{PgE}_{2}\right)$ y no IL-1 o TNF alfa, están involucrados en la quimiotaxis y fagocitosis, pero no son tumoricidas o embriocidas, son insensibles a los lipopolisacáridos (LPS) e ineficientes en tragar células extrañas y en procesar antígenos para presentarlos a los linfocitos $T$ de ayuda.

La activación de un macrófago se induce al unirse IFN-gamma a receptores especificos de su superficie, pudiendo entonces unirse a células tumorales y, posiblemente, embrionarias. Luego, los LPS de la pared celular de las bacterias gram-negativas, que normalmente no actúan sobre los macrófagos residentes, sí producen cambios en los macrófagos activados, volviéndolos cumoricidas. Se segrega peroxido de hidrógeno y radicales superoxido, 
colagenasas y proteinasas, las que alteran la superficie del cumor $y$, posiblemente, aumenta su inmunogenicidad y reconocimiento por los CTLs.

Los macrófagos también producen TNF alfa y componentes de complemento que atraen los macrófagos circulantes (monocitos) a los sitios de activación inmunológica, los que son imprimados por IFN-gamma para también responder a los LPS, incrementando la respuesta inmune mediada por células.

Los recientemente activados macrófagos producen IL-I que activa a los linfocitos $\mathrm{T}$ de ayuda a segregar IFN-ô y IL-2. Con cantidades elevadas de IL-2, las células NK desarrollan las células LAK que destruyen células trofoblásticas y tumorales. El TNF alfa y el IFN-gamma inhiben la producción de TGF-ß y de $\mathrm{PgE}$, inhibidores secundarios de la respuesta immune mediada por cé. lulas. Los macrófagos activados también producen IFN-B que inhibe la accividad de TGF- $\beta$ ('11).

El TNF alfa también induce la producción por el macrógafo de la IL-6, estímulo para la síntesis de proteínas hepáticas de fase aguda, precursores de fibrinógeno y complemento, y que activa las células LAK. TNF alfa también inhibe la síntesis de DNA por el rofoblasto e interfiere con el crecimiento de la célula epitelial. A su vez, el IFN-gamma sensibiliza las células blanco a la acción lítica del TNF alfa ( ${ }^{112}$ ). Experimentalmente, la invección de TNF alfa a pericotas no produce alteración del embarazo, salvo que sea precedida por la inyección de extracto microbiano, que activa los macrófagos y se produce el parto pretérmino. TNF alfa tiene accion sinergística con IFN-gamma para activar los genes de macrófago para antígenos clase II y muerte celular. El TNF alfa también actúa sinergísticamente con LPS para liberar el factor activador de plaquetas (PAF), producto celular inflamatorio que induce la necrosis tisular (113) y estimula las contracciones miometriales $\left({ }^{114}\right)$

Se sospecha que la infección pélvica podría ser un anlecedente importante para la ocurtencia posterior de un parto pretérmino, al quedar siempre una infección de grado menor que se incentivaría por la presencia de pocos nuevos microorganismos ( ${ }^{\mathrm{IIs}}$ ). La respuesta individual para vencer dichá inmunosupresión podría depender del gen para TNF alfa localizado en el cromosoma 6, adyacente al locus principal de histocompatibilidad. Aunque el espermatozoide $y$ el líquido seminal humanos son inmunosupresores, el eyaculado tiene cinco a seis especies diferentes de bacterias que pueden activar la respuesta inmune y sensibilizar los macrófagos deciduales (115.116.117). Los macrófagos producen $\mathrm{PgE}_{2} y_{\text {, si son } \mathrm{ac}-}$ tivados por TNF alfa producen más $\mathrm{PgE}$, luego de exposición a LPS. Por lo que, una infección influirá sobre la produccion de $\mathrm{PgE}_{2}$. La liberación de ácido araquidónico ligado a la membrana del macrófago es normalmente inhibido por IFN-ô, salvo en presencia de baclerias $\left({ }^{104}\right)$. Se conoce que la membrana amniótica contiene niveles altos de ácido araquidónico (118) y las bacterias infectivas y las que normalmente viven en la vagina (estafilococo coagulasa negativo, micoplasma y Gardnerella vaginalis) sintetizan y liberan fosfolipasa $A_{2}\left({ }^{114}\right)$ e inducen a la síntesis de $\mathrm{PgE}$, por el amnios humano $\left({ }^{120}\right)$. Por lo que. la infección bacteriana o colo- nización en el útero puede provocar el parto pretérmino en mujeres susceptibles, al inducir la producción de $\mathrm{PgE}_{2}$ al segregar fosfolipasa $\mathrm{A}_{2}$ o al activar macrófagos y linfocitos a producir citoquinas e intermediarios inflamatorios que aumentan la liberación de $\mathrm{PgE}_{2}$ por el amnios y las células del sistema inmune.

Las concentraciones del factor activador de plaquetas (PAF) están incrementadas nueve veces en el líquido amniótico del embarazo a tétmino y dos a tres veces más en la rotura prematura de membranas o en el parto pretermino. mientras la $\mathrm{PgE}_{2}$ no aumenta en la RPM sin infección ( ${ }^{123}$ ). El PAF induce contracciones del miometrio ( $\left.{ }^{122}\right)$. TNF alfa y LPS actúan sinérgicamente en inducir producción de PAF $\left({ }^{113}\right)$, mientras PAF estimula la producción de $\mathrm{PgE}_{2} \mathrm{y}$, sinérgicamente, inducirían el trabajo de parto $\left({ }^{\left({ }^{3}\right.}\right)$. El TNF alfa actuaría sólo en casos de infección. La IL-6 en líquido amniótico aumenta de $10 \mathrm{ng} / \mathrm{mL}$ a término $619 \mathrm{ng} / \mathrm{mL}$ en el trabajo de parto a $50 \mathrm{ng} / \mathrm{mL}$ o en casos de cultivos negativos pero con resistencia a la tocolisis y a $375 \mathrm{ng} / \mathrm{mL}$ con cultivos positivos y que no responden a la tocolisis $\left({ }^{123}\right)$, por lo que puede ser un buen indicador de la presencia de corioamnionitis en el parto pretermino. Si bien, la antibioticoterapia puede ayudar en algunos casos, se podría obtener mayor beneficio reduciendo la producción de $\mathrm{PgE}_{2}$, PAF, IL-2, IL-6 o la activación del sistema inmune celular mediado por TNF o aumentando la secreción local de TGF- $B$.

\section{INMUNOLOGÍA EN LA ANTICONCEPCIÓN}

Aciualmente, existe la posibilidad de desarrollar anticuerpos contra hormonas del hombre o de la mujer, contra enzinuas, líquido seminal, endometrio $\left({ }^{124}\right)$, oocitos o contra trofoblasto. El siguiente cuadro de Scott y Beer sintetiza tal posibilidad.

\section{LUGARES EN LOS QUE SE PUDIERA EMPLEAR PROCESOS INMUNOLOGICÓS PARA INHIBIR LA FER- TILIDAD}

PITUITARIA: LH, FSH
TESTICULO: TESTOSTERONA
ANTIGENOS ORGANO-
ESPECÍFICOS
SEMEN: ESPERMATOZOIDE

ENZIMAS ESPERMÁTICAS

LÍQUIDO SEMINAL

\author{
HIPÓFISIS: L.H, FSH \\ OVARIO: ESTRÓGENO \\ PROGESTERONA \\ ÚTERO: BLASTOQUININA \\ RECEPTORES HORMO- \\ NALES \\ ANTIGENOS DE EN- \\ DOMETRIO \\ TROFOBLASTO: HCG. \\ HPL \\ ANTIGENOS ÓRGANO- \\ ESPECÍFICOS
}


Experimentos realizados en animales han ocasionado la disminución de la espermatogénesis y de la líbido en el macho o la supresión de la ovulación, del estro, de la implantación o del desarrollo embrionario en la hembra. Por otro lado, la inmunización activa simultánea contra estrógenos y andrógenos en animales incrementa la ovulación. Será aspecto de interés futuro la produccion de vacunas dirigidas a neutralizar hormonas endógenas, en los diferentes niveles del eje corteza-hipotálamo-hipófisis-gonadal $\left({ }^{125.126}\right)$.

\section{REFERENCIAS BIBLIOGRAFICAS:}

1) Gell SA. Immunologic factors influencing pregnancy. Obstet Gynecol Annual 1985, pag.25-44.

2) Herrera-Gonzalez NE, Dresser DW. Fetal-maternal immune interaction: blocking antibody and survival of the fetus. Dev Comp Immunol 1993: 17: 1 .

3) Billington WD. The normal fetomaternal immune relationship. Baillieres Clin Obstet Gynaecol 1992; 6:417.

4) Pacheco J. Presencia de espermaglutininas en el suero y en las secreciones del tracto genital en mujeres infértiles. Tesis Doctoral, Prog Acad Med Hum UNMSM, 1973.

5) Peters AJ, Coulam CB. Sperrn antibodies. Am J Reprod Immunol 1992; 27: 156 .

6) Boue F, Lassalle B, Doquenne C, Villaroya S, Testart J, Lefevre A, Finaz C. Human sperm proteins from testicular and epididymal origin that participate in ferilization: modulation of sperm binding to zona-free bamster oocytes, using monoclonal antibodies. Mol Reprod Dev 1992; 33: 470 .

7) Brucker C, Sandow BA, Blackmore PF, Lipford GB, Hodgen GD. Monoclonal antibody AG7 inhibits fertilization post sperm-zona binding. Mol Reprod Dev 1992; 33: 451.

8) Alexander NJ. Reproductive immunology:relevance to infertility practice. Arch Immunol Ther Exp Warsz. 1990; 38: 23-30.

9) Candle MR. Reproductive immunology. Eo García CR, Masiroianni L, Amelar RD, Dubin L "Current Therapy of Infertility - 3". B.C.Decker Inc., Toronto-Philadelphia, 1988.

10) Goldfarb AF. Unexplained infertility. En Garcla CR, Mastroianni L, Amelar RD, Dubin L "Current Therapy of Infertility - 3". B.C.Decker Inc., Toronto-Philadelphia, 1988.

11) McShane PM, Schiff I, Trentham DE. Cellular immunity to sperm in infertile womed. JAMA. 1985; 253:3555-3558.

12) Mogbissi KS, Sacco AG, Borin K. Immunologic infertility: I.Cervical mucus antibodies and postcoital test. Am J Obstet Gynecol. 1980; 136: 941-950.

13) Pacheco-Romero J, Gleich GJ, Loegering DA, Johnson CE. Spenoagglutinating activity and female infertility. JAMA 1973; 224:849852.

14) Boehme M, Donat $\mathbf{B}$. Identification of lymphocyte subsets in the human fallopian tube. Am J Reprod Iramunol 1992; 28: 81.

15) Bronson RA. Male immunologic infertility. En García $C R$, Mastroianni L. Amelar RD and Dubin L "Current Therapy of Infertility - 3". B.C.Decker Inc., Toronto-Philadelphia, 1988.

16) Naz RK, Kapian P, Goldstein AL. Thymosin alpha-1 enhances the fertilizing capacity of human sperm cell: implication in diagnosis and treatmen of male infertility. Biol Reprod 1992; 47: 1064.

17) Lockshin MD, Druzin ML, Goei S, et al. Antibody to cardiolipin as a predictor of fetal distress or death in pregnant patients with sysiemic lupus erylhematous. N Engl J Med 1985; 313: 152.

18) Gobert B, Barbarino-Monnier P, Guillet-May F, Bene MC, Faure GC. Anti-ovary antibodies after attempts at human in vitro fertilization induced by follicular puncture rather than hormonal stimulation. J Reprod Fertil. 1992: 96: 213.
19) Stern J, Coulam CB. New concepts in ovarian regulation: in immune insigbt. Am I Reprod Immunol 1992; 27: 136.

20) Dewolf F, Carreras LO, Moerman P, Vermylen J, Van Assche A, Reaner $M$. Decidual vasculopathy and extensive placental infarction in a patient with repeated thromboembolic accidents, recurrent fetal loss, and lupus anticoagulant. Am J Obstet Gynecol 1982; 142: 829.

21) Hass GG. Immunologic factors in recurrent abortion and infertility. En García CR, Mastroianni L, Amelar RD, Dubio L "Curreal Therapy of Infertility - 3". B.C.Decker Inc., Toronto-Philadelphia, 1988.

22) Gleicher N. Autoantibodies in normal and abnormal pregnancy. Am J Reprod Immunol 1992; 28: 269.

23) Birdsall M, Pattison N, Chamley L. Antiphospholipid antibodies in pregnancy. Aust N Z J Obstet Gypaecol 1992; 32: 328.

24) Firkin BG, Howard MA, Radford N. Possible relationsbip between lupus inbibition and recurrent abortions in young women. Lancet 1980; 2: 366.

25) Lockwood CJ, Romero R, Feinberg RF, Clyne LP, Coster B, Hobbins JC. The prevalence and biologic sigaificance of lupus anticoagulant and anticardiolipin antibodies in a general obstetric population. Am J Obstet Gynecol 1989; 161: 369.

26) Lubbe WF, Liggins GC. Lupus anticoagulant, thrombosis and pregnancy. Am J Obstet Gynecol 1985; 153: 322.

27) Lubbe WF, Liggins GC. Role of lupus anticoagulant and autoimmuoity in recurent pregnancy loss. Serninars Reproductive Endocrinology 1988; 6: 181 .

28) Carreras LO, Vermylen J, Spitz B, VanAssche A. Lupus anticoagulation and inhibition of prostacyclin formation in patients with repeated abortion. intrauterine growth retardation, and intraterine death. Br J Obstet Gynaecol 1981; 88: 890.

29) Editorial. Lupus anticoagulant. Lancet $1984 ; 1: 1157$.

30) SanFelippo MJ, Drayna CJ. Prekallikrein inhibition associated with lupus anticoagulant. Am J Clin Pathol 1982; 77: 275.

31) Crosgriff TM, MArtin BA. Low functional and high antigenic antithrombin III level in a patient with the lupus anticoagulant and recurrent thrombosis. Arthritis Rheum 1981; $24: 94$.

32) Branch DW, Scott JR, Kochenour NK, Hershgold M. Obstetric complications associated with the lupus anticoagulant. N Engl J Med 1985: 313: 1322

33) Gregorini G, Setti G, Remuzzi G. Recurrent abortion with lupus anticoagulant and pre-eclampsia: a common final pathology for two different diseases? Br J Obstet Gynaecol 1986: 93: 194.

34) Gleicher N, Harlow L, Zilberstein M. Regulatory effect of antiphospholipid antibodies on signal transduction: a possible model for autoantibody-induced reproductive failure. Am J Obstet Gynecol 1992; 167:637.

35) Mueb JR, Herbst KD, Rapaport SI. Thrombosis in patients with the lupus anticoagutant. Ann Intem Med 1980; 92: 156.

36) Shown RT, Trentham DE. Drug induced lupus: an adjuvant disease? Am J Med 1981; $71: 5$.

37) Rix P, Stentoft J, Auncholt NA, Deeholm M, TUlma KA, Hoier-Madsen M. Lupus anticoagulant and anticardiolipin antibodies in an obsterric population. Acta Obstet Gynecol Scand 1992; 71: 605.

38) Triplett DA, Harris EN. Antiphospbolipid antibodies and reproduction. Am J Reprod Immunol 21: 123-31, 1989.

39) Derue GJ, Englert EJ, Harris EN, Gharavi AE, Morgan SH, Bull RG. Fetal loss in systemic lupus in association with anticardiolipin antibodies. Br J Obstet Gynaecol 1985; 5: 207

40) Reece EA, Ganrielli S, Cullen MT, Zheng $X$, Hobbins JC, Harris EN. Recurrent adverse pregnancy outcome and antiphospholipid antibodies. Am J Obstet Gynecol 1990; 163: 162.

41) Harris E, Chan J, Asherson R, et al. Thrombosis, recurrent fetal loss, and thrombocytopenia. Arch Intern Med 1986; 146: 2153.

42) Brown HL. Antiphospholipid antibodies and recurent pregnancy loss. Clin Obsiet Gynecol 1991; 34: 17. 
4.3) Hull RG. Harrí EN, Morgan $S H$, et al. Anti-Ro antibodies and abontions in Homen with SLE. Lancel 1983: 2: 1138.

44) Hellgren M, Tengburn L, Abidgrand U. Pregnancy in women wilh congenital antithrombin III deficiency. Gynecol Obstet Invest 1982: 14: 127.

45) Rosove MH, Tabsb $K$, Howard $P$, et al. Heparin therapy for prevention of fetal wastage in women with anticardiolipin antibodies and lupus anticoagukanls. Blood 1987; 70: 379a.

46) Rosove MH, Tabsb $K$, Wasserstrum N, Howard $P$, Habn BH, Kalunian KC, Heparin therapy for pregnant women with lupus anticoagulant or anticardiolipin antibodies. Obstel Gynecol 1990; 75: 630.

47) Castro O, Farver LR, Clyne LP. Circulating anticoagulants against factor IX and $X I$ in systemic lupus erylehmatosus. Ann Intern Med 1972; 77: 543.

48) Scott Jr, Branch DW, Kochenour NK, Ward K. Intravenous immunoglobulin treatment of pregnant patients with recurent pregnancy loss caused by antiphospholipid antibodies and Rh immunization. Am J Obslet Gynecol 1988: 159: 1055.

49) Boyd PA, Lindenbaum RH, Redman C. Preeclampsia and trisomy 13: a possible association. Lancel 1987: 2: 425.

50) Bailey K, Berrod HC, Younger R, Shaver D. Functional aspects of T. lymphocyle subsets in pregnancy. Obstel Gynecol 1985; 66: 211.

51) Massobrio M, Benedetto C, Bertini E, Tetta C, Camussi E. Immune complexes in pre-eclampsia and normal pregnancy. Am J Obtel Gynecol 1985: 152: 578 .

52) Sridman V, Yang SL, Moawad A, Degroot W. T-cells subsets in patients with preeclampsia. Am J Obstel Gynecol 1983; 147: 566.

53) El-Rociy A. Gleicher N. The immunologic concepl of pre-eclampsia. En Rubin PC "Handbook of Hypertension", Vol. 10, Elsevier Science, Amsierdam, 1988.

54) Moore MP, Carter NP, Redman CWG. Lymphocyte subsets in normal and pre-cclamptic pregnancies. Br J Obstet Gynaecol 1983: 90: 326.

55) Mel'nikor VA, Kupaer IA, Lipator IS. (Anti-vascular antibodies in women with physiological pregnancy and pregnancy complicaled by gestosis]. Akush Ginekol Mosk 1992 (3.7): 19.

56) Sibai BM. Immunologic aspects of preeclampsia. Clin Obstel Gynecol 1991: 34: 27.

57) Redman CW. Immunological aspects of pre-eclampsia. Baillieres Clin Obstet Gynaecol 1992; 6: 601.

58) Feeney JG. Preeclampsia and changed paternity. En: Bonnar J MacGillivray I, Symmonds EM "Pregnancy Hypenension". University Park Press, Baltimore, 1980.

59) Serhal P. Cragt $\mathbf{H}$. Immune basis por pre-eclampsia: evidence from oocyte recipients. Lancet 1987; 1: 744 .

60) Klonoff-Cohen HS, Savitz DA, Celalo RC, McCann MF. An epidemiologic study of contraception and preeclampsia. JAMA 1989; 262: 3143.

61) Campbell D, MacGillivray I, Carr-Hill P. Preeclampsia in second pregmancy. Br J Obstel Gynaecol 1985; 92: 131.

62) Sibai BM, EI-Nazer A, Gonzalez-Rulz AR. Severe preeclampsia-eclampsia in young primigravidas: subsequent pregnancy outcome and remote prognosis. Am J Obstel Gynecol 1986; 155: 1011.

63) Redman CWG, Bodmer WF, Bodmer JG, Beilin LJ. HLA anligens in severe preeclampsia. Lancet 1978: 2:397.

64) Kllpatrick DC, Gibson F, Liston WA, Livingston J. Association between susceptibility to pre-eclampsia within families and HLA DR4. Lancet 1989: 2: 1063.

65) Christiane Y, Aghayan M. Emonard H, Lallemand A, Mahteu P, Foidart JM. Galactose alpha 1-3 galactose and anti-alpha galaciose antibody in normal and pathological pregnancies. Placenta 1992: 13: 475.

66)Giordano C, De-Maria R, Mattina A, Stassi G, Todaro M, Pugliese A, Galluzzo G, Botta RM, Galluzzo A. Analysis of T-lymphocyte subsets after phytohemagglutinin stimulation in normal and type 1 diabetic molhers and their infants. Am J Reprod Immunol 1992; 28: 65.

67) Sigmon JM. Basic principles of the ABO and Rh blood group systems for hemapheresis praclitioners. J Clin Apheresis 1992; 7: 158.

68) Jackson GM, Scotl JR. Alloimmune conditions and pregnancy. Baillieres Clin Obstet Gynaecol 1992; 6: \$41.

69) Gimovsky ML, Benner P, Montoro M, et al. Successful pregnancy in a patient with SLE, renal transplantation and chronic renal failure. J Reprod Med 1983; 28: 677 .

30) Gimorsky ML, Montoro M, Paul RH. Preganancy outcome in women with SLE. Obstel Gynecol 1984; 63; 686.

71) Gimovsky ML, Montoro M. Syslemic lupus erythernatosus and other connective tissue diseases in pregnancy. Clin Obstet Gynecol 1991: 34: 35.

72) Tan EM. Special antibodies for the study of systemic lupus erythernatosus: an analysis. Arthitris Rheum 1982: 25: 753.

73) Scherak O, Smolen JS, Mayr WR. HLADRW3 and SLE. Arthritis Rheum 1980; 23: 954.

74) Steinberg AD, Raveche ES, Laskin CA, et al. SLE: insights from arimal models. Ann Intern Med 1984; 100: 714.

75) Abramson SB, Buyon JP. Activation of the complement pathway: comparison of normal pregnancy, preeclampsia, and systemic lupus erythemalosus during pregnancy. Am J Reprod Immunol 1992: 28: 183.

76) Finec LG, Barnett EV, Danovitch GM, et al. SLE in pregnancy. Ann Inlem Med 1981: 94: 667

77) Pacbeco J. Manual de Obstetricia. Editorial San Miguel. 1994.

78) Huaman M, Carrillo L, Mayorga G, Pacheco J, Vidalón A. Embarazo posi transplante renal. Ginecol Obstel Perú 1990: 36: 16.

79) Abramovosky CR, Vegas ME, Swinebart G, et al. Decidual vasculopathy of the placeata in lupus erythemalosus. N Engl J Med 1980: 303: 668 .

80) Scott JS, Maddison PJ, Taylor PV, et al. Conneccive tissue disease. antibodies to ribonucleoprotein and congeniral heart block. N Engl J Med 1983: 309: 209.

81) Nelson JL, Koepsel TD, Dugowson CE, Voigt LF, Daling JR, Hansen JA. Fecundity before disease onset in women with rheumatoid arthritis. Arthritis Rheum 1993: 36: 7.

82) Moise KJ. Autoimmune thrombocylopenic purpura in pregnancy. Clin Obstet Gynecol 1991; 34: S1.

83) McMillan R. Chronic idiopathic thrombocylopenic pupura. N Engl J Med 1981: 304: 1135 .

84) Gernsheimer T, Stratton J, Ballem PJ, Slichter SJ. Mechanism of response 10 treatment in autoimmune thrombocytopenic purpura. New Engl J Med 1989; 320: 974.

85) O'Reilly RA, Tober B. Immunologic thrombocytopenic purpura and pregnancy. Obsiel Gynecol 1978: 51: 590 .

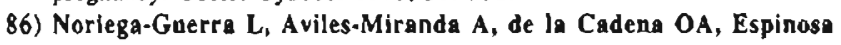
IM, Chavez F, Plzzuto J. Pregnancy in patients with autoimmune thrombocytopenic pupura. Am J Obstet Gynecol 1979: 133: 439.

87) Molse KJ, Carpenter RJ, Cotton DB, Waserstrum N, Kirsbon B, Cano L. Perculaneous umbilical cord sampling in the evaluation of fetal platelet counts in pregnant patients with autosome thrombocytopenic purpura. Obsiet Gynecol 1988: 72: 346.

88) Scioscia AL, Grannum PA, Copel JA, Bobbins JC. The use of percutaneous umbilical blood sampling in immune thrombocytopenic purpura. Am J Obstet Gynecol 1988; 159: 1066.

89) Strother SV, Wagner AM. Prednisone in pregnant women with idiopahic thrombocytopenic purpura. N Engl J Med 1988: 319: 178.

90) Levitz M. Jansen V, Dancls J. The transfer and metabolism of conicosteroids in the perfused human placenta. Am J Obstet Gynecol 1978: 132: 363 .

91) Fehr J, Hofrman V, Kappeler U. Transient reversal of thrombocylopenia in idiopathic thrombocylopenic purpura by high-dose intravenous gamma globulin. N Engl J Med 1982; 306: 1254. 
92) Pappas C. Placental transfer of immunoglobulins is immune thrombocytopenic purpura. Lancet 1986; 1: 389.

93) Moise KJ, Cano LE, Sala DJ. Resolution of severe thrombocytopenia in a pregnant patient with rhesus-negative blood with autoimmune thrombocytopenic purpura after intravenous rhesus immune globulin. Am J Obstel Gynecol 1990; 162: 1237.

94) Schreiber AAD, Chien P, Tomaski A, Cines DB. Effect of darazol in immune thrombocytopenic purpura. N Engl J Med 1987; 316: 503.

95) Davison JM, Dellagrammatikas B, Parkin JM. Materna) azathioprine therapy and depressed haemopoiesis in the babies of renal allograft patients. Br J Obstet Gynaecol 1985; 92: 233.

96) Gililland J, Weinstein L. The effects of cancer chemotherapeutic agents on the developing fetus. Obstet Gynecol Survey 1983: 38: 6 .

97) Nicholson HO. Cytotoxic drugs in pregnancy: seview of reported cases. Br J Obstet Gynaecol 1968: 75: 307.

98) Sims CJ. Organ transplantation and immunosuppressive drugs in pregnancy. Clin Obstet Gynecol 1991; 34: 100.

99) Penn I, Makowski EL, Harris P. Parenthood following renal transplantation. Kidney Int 1980, 18: 221.

100) O'Connell PJ, Caterson RJ, Stewart JH, Mahony JF. Problems associated with pregnancy in renal allograft recipients. Int J Artif Organs 1989; 12: 147

101) Bou S. Pregnancy in organ transplant recipients. Med Clin North Am 1989: 73: 667.

102) Lau RJ, Scott JR. Pregnancy following renal transplantation. Clin Obstet Gynecol 1985: 28: 339.

103) Lowenstein BR, Vain NW, Perrone SV, Wright DR, Boullon FJ, Falvalora RG. Succesful pregnancy' and vaginal delivery after heart transplantation. Am J Obstet Gynecol 1988; 158: 589.

104) Weinberg ED. Pregnancy associated depression of cell mediated immunity. Rev Infec Dis 1984; 6: 814.

105) Diro M, Beydoun SN. Malaria in pregnancy. South Med 1982: 72: 959.

106) Smale LE, Waechter KG. Dissemination of coccidioidomycosis in pregnancy. Am J Obstet Gynecol 1970; 107: 356.

107) Yancey MK. Host defenses and bacterial resistance. Obstet Gynecol Clin North Am 1992; 19: 413.

108) Clark DA. Controversies in reproductive immuoology. Crit Rev Immunol 1991: 11: 215.

109) Witkin S, McGregor JA. Infection-induced activation of cell-mediated immunity: possible mechanism for preterm birth. Clin Obstet Gynecol 1991: 34: 112

110) Romero R, Mazor M, Brandt F, Sepulveda W, Avila C, Cotton DB, Dinarello $C A$. Interleukin- 1 aspha and interleukin- 1 beta in precerm and term human parturition. Am J Reprod Immunol 1992; 27: 117.

111) Hunt JS. Immunobiology of pregnancy. Curr Opin Immunol 1992; 4: 591.
112) Fcinman R, Henriksen-DeStefano D, Tsujimoto $M$, et al. Tumor necrosis factor is an important mediator of tumor cell killing by human monocyles. J Immunol 1987; 138: 635.

113) Sun XM, Hsueh W. Bowel necrosis induced by tumor necrosis factor in rats is medjated by placelet-activating factor. J Clin Invest 1988; 81: 1328.

114) Clark DA, Slapsys $R$, Chaput $A$, et al. Immunoregulatory molecules of throphoblast and decidual suppressor cell origin at the matemofetal interface. Am I Reprod Immunol Micrabiol 1986; 10: 100.

115) Toth $M$, Wilkin SS, Ledger $W$, e al. The role of infection in the etiology of preterm birth. Obstet Gynecol 1988: 71: 723.

116) Billier SL, Rabe LK, Muller CH, et al. Relationship of bacteriologic characteristics to semen jodices in men attending an infertility clinic. Obstet Gynecol 1990; 75: 800.

117) Witkin SS. Failure of sperm-induced immunosuppression: association with anti-sperm antibodies in women. Am J Obstet Gynecol 1980;160: 1166.

118) Curbelo V, Bejar R, Benirschke $K$, et al. Premature labor. I. Prostaglandin precursors in human placental membranes. Obstet Gynecol 1981: 57: 473.

119) Bejar R, Curbelo V, Davis C, et al. Premature labor. II: Bacterial sources of phospholipase. Obstec Gynecol 1981: 57:479.

120) Lamont RF, Anthony F, Myatt L, et al. Production of prostaglandin E2 by human amnion in vitro in response to addition of media conditioned by microorganisms associated with chorioamnionitis and preterm labor. Am J Obstet Gynecol 1990; 162: 819.

121) Romero R, Emamian $M$, Wan $M$, et al. Prostaglandin concentrations in amniotic fluid of women with intra-amniotic infection and preterm labor. Am J Obstet Gynecol 1987; 157: 1461.

122) Hoffman DR, Romero R, Johnston JM. Detection of platelet-activating factor in amniotic fluid of complicated pregnancies. Am J Obstet Gynecol 1990; 162: 525.

123) Romero R, Avila C, Santhanam U, et al. Amniotic fluid interleukin-6 in preterm labor: association with infection. J Clin Invest 1990; 85:1392,

124) Ravn V, Teglbjaerg CS, Mandel U, Dabelsteen E. The distribution of type-2 chain histo-blood group antigens in normal cycling human endornetrium. Cell Tissue Res 1992: 270: 425.

125) Reeves JJ, Chang CF, deAvila DM, Grieger DM, Johnson RE, Roberts AJ. Vaccines against endogedous hormones: a possible future cool in animal production. J Dairy Sci. 1989: 72: 3363-71.

126) Roberts AJ, Reeves JJ: Reproductive and endocrine changes in ewes actively immunized against estrogens and androgens. I Reprod Immuno] 1991: 19: 179-95. 